\title{
Contemporary Opinion
}

\section{O Opioids and Neuropathic Pain}

Howard S. Smith, MD

From: Albany Medical College, Albany, NY

Dr. Smith is Professor and Academic Director of Pain Management at Albandy Medical Collee, Albany, NY.

Address correspondence: Howard S. Smith, M.D. Professor \& Academic Director of Pain Management Albany Medical College Department of Anesthesiology 47 New Scotland Avenue; MC-131 Albany, New York 12208 Phone: $518-262-4461$ Fax: 518-262-2671 smithh@mail.amc.edu

Disclaimer: There was no external funding in the preparation of this manuscript.

Conflict of interest: None.

Manuscript received:11/og/2011 Accepted for publication: 02/09/2012

Free full manuscript: www.painphysicianjournal.com
Opioids are broad spectrum analgesics that may be beneficial to alleviate the intense perception of algesia in patients suffering with pain. They have been one of the most controversial analgesics, in part because of their potential for addiction. Opioids or any currently available analgesic will not provide effective analgesia for every patient with chronic neuropathic pain (NP), but overall opioids are considered to be a second or third line class of analgesics that may provide reasonable analgesia to some patients with chronic NP. Although opioids may alleviate chronic NP, overall, NP tends to be less opioid responsive than nociceptive pain. The mechanisms that may contribute to neuropathic pain may simultaneously also contribute to diminishing the antinociceptive properties of opioids for neuropathic pain. Some of these mechanisms may also contribute to analgesic tolerance and/or opioid-induced hyperalgesia. Hyperalgesia consequently to nerve insult and opioidinduced analgesic tolerance, may both involve the N-methyl-D-aspartate (NMDA) receptor and share part of intracellular events producing a state of neural hyperexcitation. Conversely, opioid therapy may contribute to nociceptive processes that may be involved in neuropathic pain such as opioid-induced cholecystokinin release. Furthermore, within NP, peripheral NP appears to be the most opioid responsive, followed by spinal NP while supraspinal NP tends to be the least responsive to opioids. Although, there is no robust evidence that any specific opioid agent is better than any other opioid at effectively treating NP, it is conceivable that some opioids/opioid-like analgesic agents may be particularly well suited to alleviate NP in certain patients suffering from neuropathic pain.

Key words: Pain, neuropathic, opioids, oxycodone, methadone, buprenorphine, tramadol, tapentadol

Pain Physician 2012; 15:ES93-ES110 n 1988 Arnér and Meyerson (1) published an article in Pain titled "Lack of an effect of opioids on neuropathic and idiopathic forms of pain." Two years later, Portenoy and colleagues (2) published an article in the same journal criticizing Arnér and Meyerson (1), stating the following points: opioid responsiveness is a continuum, rather than a quantal phenomenon; opioid responsiveness is determined by a diverse group of patient characteristics and pain-related factors, as well as drug-selective effects; and a neuropathic mechanism may reduce opioid responsiveness, but does not result in an inherent resistance to opioid therapy.

Arnér and Meyerson ( 3 ) responded by stating that although the title of their paper had a somewhat pro- vocative phrasing, it should be perfectly clear that nowhere in the text did they maintain that the issue of responsiveness of neuropathic pain (NP) to opioids is finally settled, nor did they suggest that any "patient in pain should be deprived of an open trial" of the analgetic efficacy of opioids. They further stated that they used opioids to treat some patients with NP in their clinical practice and that the essence of their message was to emphasize the need for further, well controlled studies of opioid responsiveness with particular regard to the pathophysiology of different pain mechanisms (3).

Over the next two decades multiple studies were published supporting the efficacy of opioids for NP (4-8). In 2005, 17 years after the initial Arnér and 
Meyerson article, Eisenberg et al published a landmark article in the Journal of the American Medical Association which essentially should have put an end to any residual controversy regarding the efficacy of opioids for NP (9). In that article, Eisenberg and colleagues demonstrated that opioids can clearly provide effective analgesia for NP. This does not mean that opioids will alleviate all NP just as opioids will not alleviate all nociceptive pain, however, opioids may effectively provide clinically meaningful analgesia for a significant proportion of patients with NP (9). Eisenberg and colleagues (9) found that shortterm studies provide only equivocal evidence regarding the efficacy of opioids in reducing the intensity of NP and intermediate-term studies demonstrate significant efficacy of opioids over placebo for NP, which is likely to be clinically important. They reported adverse events of opioids are common but not lifethreatening and concluded that further randomized controlled trials (RCTs) are needed to establish their long-term efficacy, safety (including addiction potential), and effects on quality of life (9). A year later Eisenberg and colleagues (10) published that shortterm studies reveal opioids can reduce the intensity of dynamic mechanical allodynia and perhaps of cold allodynia in peripheral NP. They reported insufficient evidence precludes drawing conclusions regarding the effect of opioids on other forms of evoked NP, and that a meta-analysis of intermediate-term studies demonstrated the efficacy of opioids over placebo for evoked NP (10).

Other factors may play a role in determining opioid responsiveness for specific NP states (11). Edwards and colleagues (11) demonstrated that basal heat pain thresholds predict opioid analgesia in patients with postherpetic neuralgia. During opioid treatment, a greater reduction in pain and higher ratings of pain relief were observed in patients with relatively higher heat pain thresholds at baseline. Other individual difference variables such as age and baseline pain intensity also significantly predicted opioid responses (i.e., higher baseline pain and younger age were related to greater opioid-associated pain reduction, with nearly $20 \%$ of the variance in opioid analgesia explained by these 2 factors) (11).

There is no robust evidence regarding the comparative effectiveness of opioids for neuropathic versus nociceptive pain. Multiple investigators have reported that opioids have similar efficacy for neuropathic and nociceptive pain $(9,12,13)$, however, Smith feels it is likely that overall, nociceptive pain is somewhat more responsive to opioids than NP (14).

In 2009, Mercadante et al, (15) evaluated tools for identifying NP in cancer pain as well as the opioid responsiveness of NP and non-NP in patients with cancer pain. They investigated the value of evaluation tools such as the Neuropathic Pain Questionnaire (NPQ), both complete and short form (NPQSF), the Leeds Assessment of Neuropathic Signs and Symptoms (LANSS), and the Neuropathic Pain Symptom Inventory (NPSI) (15). The secondary outcome was to evaluate the response to opioid titration, according to the hierarchical classification of definite, possible, and unlikely NP. Patients with uncontrolled cancer pain requiring adjustment of opioid therapy were clinically classified into tertiles according to the graded evidence of their nervous system lesion: definite NP, possible NP, or unlikely NP. Pain and symptom intensities were measured before (T0) and at the end of opioid titration (T1) (15). Sixty, 36, and 71 patients were clinically assessed as having definite NP, possible NP, or unlikely NP, respectively. A relationship between the values of the assessment tools and clinician rating was found. Patients with the highest values of assessment tools were also more likely to be clinically labeled as definite NP. Patients with a clinical diagnosis of definite NP, possible NP, or unlikely NP showed significant differences in their analgesic response to opioids $(P<.0005)$. Patients with "unlikely NP" had a lower pain intensity at T1 $(P<.05)$, and patients with "definite NP" required more intensive opioid treatment. Patients requiring more aggressive opioid treatment showed significantly higher values of Opioid Escalation Index (OEI) milligrams (i.e., higher opioid doses) (15). Thus, the research of Mercadante et al (15) appears to confirm that opioids are clinically effective for NP in cancer patients. Their findings also appear to support the notion that NP tends to be less responsive to opioids than non-NP (i.e., nociceptive pain) (15).

Furthermore, as previously stated, although definitive evidence does not exist, and at least one investigator has reported otherwise (that opioid responsiveness is roughly equal in peripheral and central NP) (9), it is likely that, overall, peripheral NP is somewhat more responsive to opioids than central NP (16). Additionally, within central NP it appears likely that supraspinal central NP is less responsive to the analgesic effects of opioids than spinal central NP (16) (Fig. 1). 


\section{Poorly Opioid Responsive}
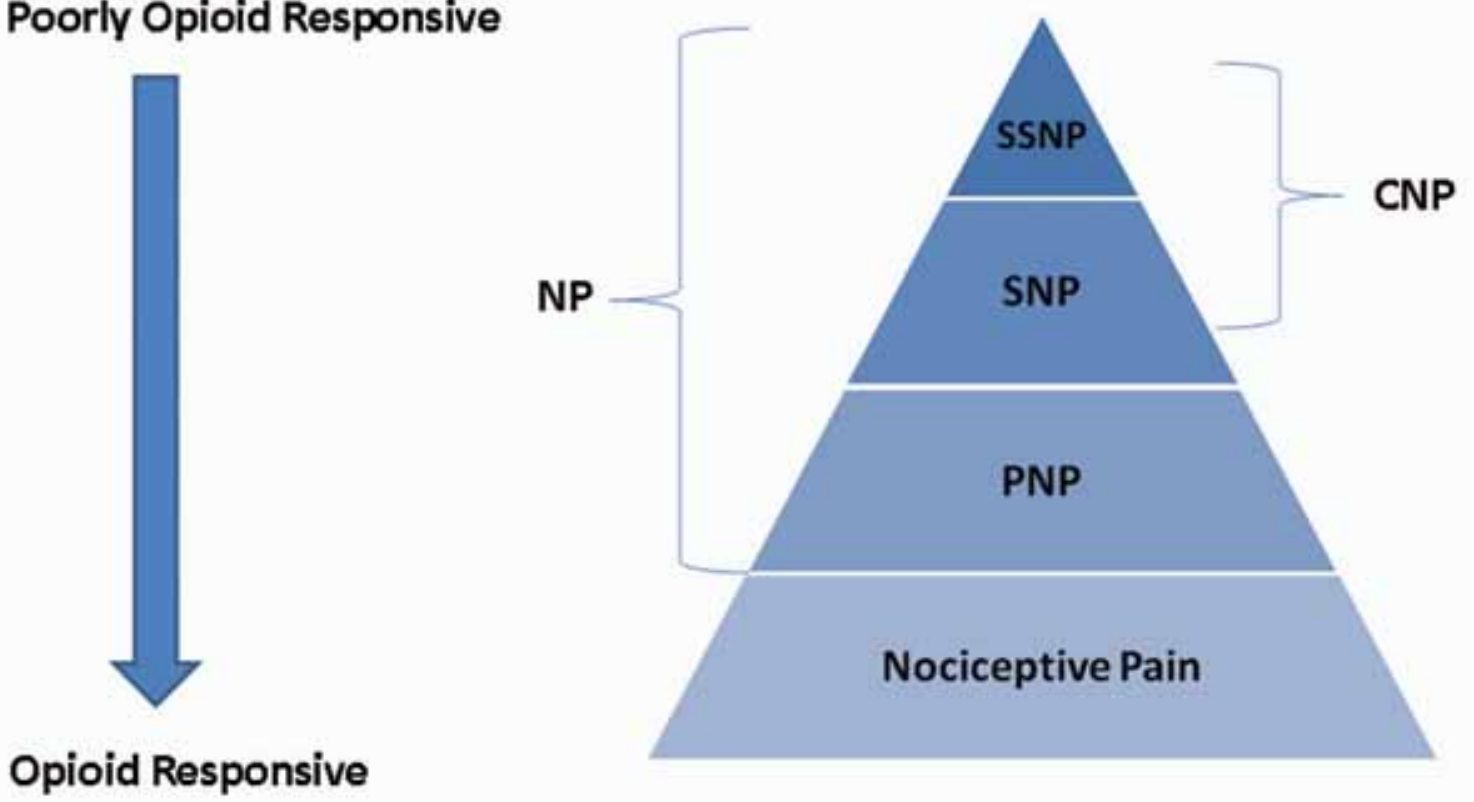

NP = Neuropathic Pain; CNP - Central Neuropathic Pain; PNP = Peripheral Neuropathic Pain SNP = Spinal Neuropath Pain' SSNP = Supraspinal Neuropathic Pain

Fig. 1. Relative overall opioid responsiveness of different categories of Pain

\section{Pathophysiologic Changes in Neuropathic Pain States}

There are numerous alterations/perturbations that may occur in the nervous system after a neural insult. These changes may vary with the type and extent of injury. Furthermore, despite many decades of intense investigation, the precise changes that play a crucial role in the development and/or maintenance of NP in humans remain uncertain. It is likely that some changes that occur are essentially epiphenomena, some changes are primarily directed toward rebuilding and growth of the peripheral nerve as well as restoring normal axonal transport and target contact, and some changes may be vital in leading to the development of chronic NP. The many changes occurring with neural insult may include upregulation of neuropeptide $\mathrm{Y}$ (NPY), ATP release/ upregulation of purinergic receptors, altered gamma amino butyric acid (GABA) signaling, chemokine alterations, ion channel alterations, changes in protein kinase $\mathrm{C}$ activity, changes in N-methyl-D-aspartate (NMDA) receptor activity, as well as changes in levels of nociceptin and nociceptin opioid peptide receptor (17-21).

If precise pathophysiologic mechanisms of various pain states were known for a particular patient, then attempts could be made in efforts to match particular treatment strategies targeted against these mechanisms (e.g., giving "blockers of dynorphin receptors" [kappa opioid receptors, NMDA receptors] for an increase in dynorphin).

Since the crucial pathophysiologic mechanisms of NP remain uncertain, it goes without saying that the precise mechanisms which may account for the reduced efficacy of opioids in certain NP states also remain elusive. Some investigators have suggested that this reduced opioid responsiveness is due to disturbances of normal opioid mechanisms/signaling in the spinal cord $(22,23)$, since the analgesic efficacy of opioids is significantly reduced from an intrathecal opioid injection compared with an intraperitoneal opioid injection for NP states $(24,25)$. One of the theories proposed for the 
reduced effectiveness of opioids for NP is due to a fundamental functional change in the dorsal horn spinal cord that occurs during NP states involving downregulation or desensitization of $\mu$-opioid receptors.

Functional downregulation and/or desensitization of $\mu$-opioid receptors in the dorsal horn of the spinal cord (but not a significant decrease in number), has been observed in nerve-injury neuropathy $(23,26)$ and diabetic neuropathy $(27,28)$, and may be related to increased production of protein kinase C (29-32).

In the brain, it appears that mu-opioid receptors are also functionally downregulated or desensitized in NP states (33), which may contribute to the reduced efficacy of opioids in NP. Hoot and colleagues demonstrated this in the thalamic region of mice in a rodent model of NP (34). [(3) H]Naloxone binding in membranes of the thalamus showed no significant differences in $B(\max )$ values between chronic constrictive injury (CCI) (and sham-operated mice, indicating that the difference in G-protein activation did not result from differences in $\mu$-opioid receptor levels. $\mathrm{CCl}$ induced a region-specific adaptation of $\mu$-opioid receptor-mediated G-protein activity, with apparent desensitization of the $\mu$-opioid receptor in the thalamus and periaqueductal gray (PAG) .) which could have implications for treatment of NP (34).

Mu-opioid receptor (MORdesensitization secondary to NP appears to involve protein kinase $A$. It has been demonstrated that the MOR and the NMDA receptors coexist at certain postsynapses and that both receptors show an electrophysiological interaction in individual neurons (35). Therefore, protein kinase A (PKA) may be responsible for the dissociation of NR1 subunits from MORs, which occurs as a result of $\mathrm{N}$ methyl-D-aspartate receptor (NMDAR)activation leading to MOR Ser phosphorylation and uncoupling from G-proteins (35) (Fig. 2).

Increased NMDA activity did not alter the normal morphine analgesic effect. Although NMDA did not promote a substantial reduction of MOR or NR1 subunits (NMDARs) in the PAGsynaptosomal preparation, it greatly increased the Ser phosphorylation of the

\section{Periaqueductal Grey}

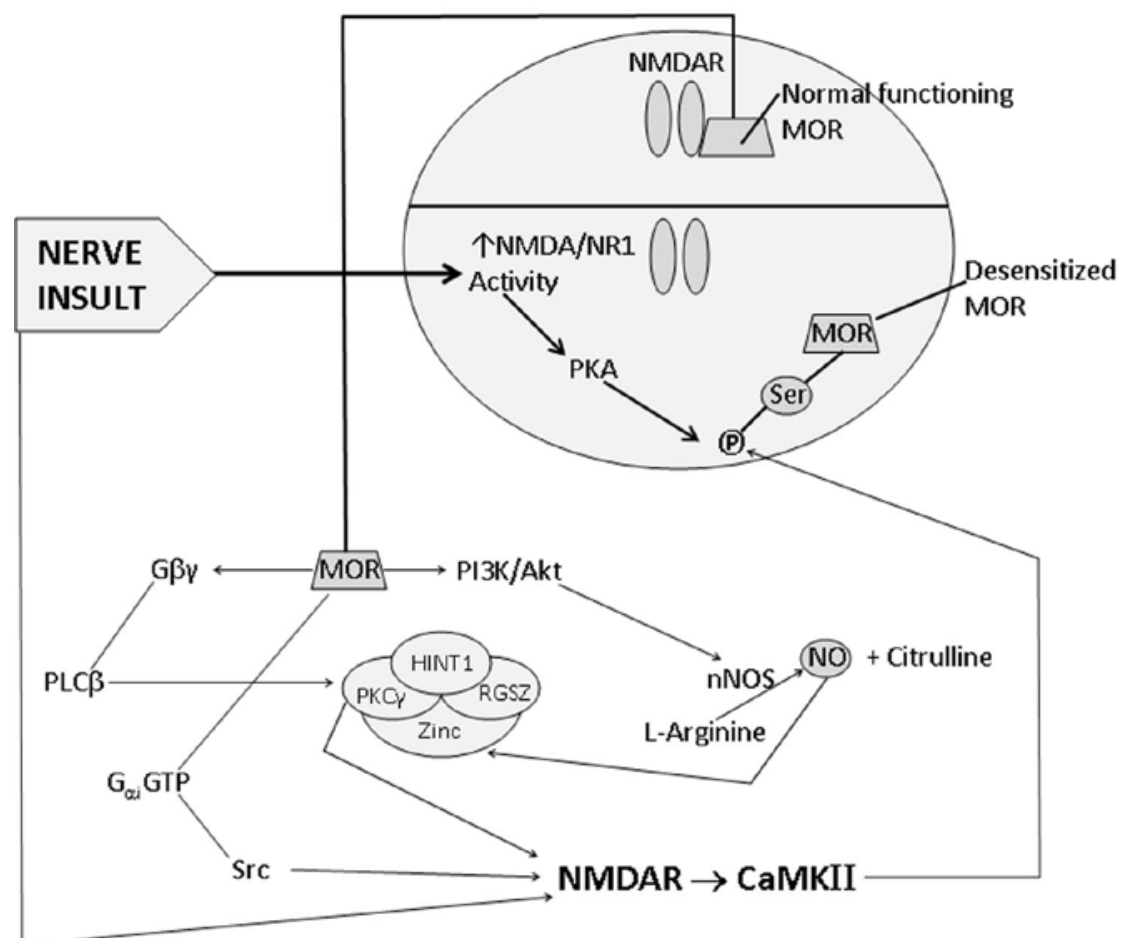

Fig. 2 .Schematic of Neuropathic Pain leading to desensitized MORs 
MOR and the uncoupling of the MOR from the regulated G-proteins. These desensitizing changes were accompanied by reductions in MOR-NR1 coprecipitation (35).

It is also conceivable that the increase of protein kinase $C$ in the dorsal horn of the spinal cord, seen with various NP states, may be due in part to activation of NMDARs in postsynaptic cells $(29,36)$, or due to an autophosphorylation of the TrkB receptor by brain-derived neurotrophic factor (BDNF) (37-39). In fact, the development of the hyperalgesia and allodynia in NP states is suppressed by administration of NMDA receptor antagonists, TrkB/Fc chimera protein (sequesters endogenous BDNF), or protein kinase $\mathrm{C}$ inhibitors (36,38-40).

It has been proposed that morphine stimulates the production of nitric oxide (NO) through MORG $\beta \delta$-PI3K-Akt-nNOS (41), which releases zinc ions from endogenous stores to recruit PKC $\delta$ and Raf-1 to the HINT1 protein at the MOR C-terminus $(42,43)$. Then, PKC $\delta$ causes MOR-NR1 separation and produces the sustained potentiation of NMDAR calcium currents by activating Src (44), and also the Raf-1-ERK $1 / 2$ cascade (43). Afterwards, NMDAR-regulated CaMKII promotes MOR phosphorylation and its uncoupling from, regulated G-proteins $(35,45)$.

Thus it appears that morphine recruits PKC to separate both receptors in PAG e )neurons (35). Zinc ions promote PKC translocation from the soluble phase to the membrane, enhancing their affinity for phorbol esters or diacylglycerol, and since high zinc levels stabilize their binding to the regulatory domain, PKC activation persists for long intervals $(42,46,47)$.

An endogenous opioid peptide dynorphin $A$ also is increased in the dorsal spinal cord after neural insult. Immunoreactivity for dynorphin $A$ and mRNA level of prodynorphin are increased in the ipsilateral dorsal spinal cord $(48,49)$. Dynorphin A, originally identified as an endogenous $\kappa$-opioid peptide, also acts as an agonist for the NMDA receptor. The administration of antiserum against dynorphin $A$ inhibits hyperalgesia/allodynia after sciatic nerve ligation (SNL). Also, hyperalgesia/allodynia is not observed after SNL in dynorphin knockout mice (49). An increase in dynorphin A has been suggested to be involved in the diminished opioid responsiveness that may be seen in NP states (50).

Hahm and colleagues (51) found that although the inhibitory effect of MOR activation on presynaptic GABA release is similar in both neuropathic and normal rats, NP may inhibit endogenous analgesia in the periaqueductal gray (PAG) through an increase in presynaptic GABA release (51). Thus, although the effect of MOR activation on presynaptic GABA release in neuropathic rats is similar to that in normal animals, exogenous opioid agonists may exert their analgesic actions less effectively in neuropathic rats due to the increased presynaptic GABA release from NP (51).

Changes in ion channel expression may also contribute to the development or maintenance of NP. Following peripheral nerve insult, the expression of several subtypes of voltage-dependent $\mathrm{Na}+$ channels (Nav1.1 Nav1.3, Nav1.7, Nav1.8, Nav1.9), may be altered in the primary afferent neuron and secondary dorsal horn neuron $(52,53)$. Pain-related behaviors after peripheral nerve injury are ameliorated by the suppression of $\mathrm{Na}+$ channel expression by antisense oligodeoxynucleotides (52).

Ion channel expression in peripheral neurons is dependent on target contact and neurotrophic support $(54,55)$. It is possible that axotomy, by downregulating $\mathrm{Ca} 2+$ channels (56), may impede the release of neurotransmitters from primary afferent terminals in the dorsal horn (57). This contrasts with the effects of chronic constriction injury $(\mathrm{CCl})$, reported to increase the expression of $\mathrm{N}$-type calcium channels in the dorsal horn (57).

There appears to be increased expression of the $\alpha 2-\delta 1$ subunit of voltage-dependent calcium channels also reported after peripheral nerve injury $(43,59)$. Gabapentin, a calcium channel blocker binding to the $\alpha 2$ $\delta 1$ subunit of the $\mathrm{N}$-type voltage-dependent calcium channel, can inhibit the hyperalgesia/allodynia occurring after SNL (59). Selective antagonists for N-type calcium channels may also suppress the hyperalgesia/ allodynia of NP states $(39,60)$.

Nociception (NOCacts similarly to traditional opioids as it produces membrane hyperpolarization through the opening of potassium channels $(61,62)$; however, in contrast to endogenous opioids (e.g., DYN), NOC does not act on any classical opioid receptors because of its lack of an $\mathrm{N}$-terminal tyrosine (63-65) NOC (Phe-Gly-Gly-Phe-Thr-Gly-Ala-Arg-Lys-SerAla-Arg-Lys-Leu-Ala-Asn-Gln), which was previously known as orphanin FQ (OFQ) (66), is produced from the precursor prepronociceptin (PNOC); (67-70) and is an endogenous ligand of the nociceptin-opioid peptide (NOP) receptor, which was previously known as opioid receptor like-1 (ORL1).

Multiple studies have supported the finding that 
the analgesic effectiveness of NOC and other NOP receptor ligands is increased with neuropathic conditions $(71,72)$ and that this effect is associated with the upregulation of NOP receptor mRNA in the spinal cord and dorsal root ganglia (DRG) (73). The potentiation of morphine effectiveness by NOP antagonists in NP has also been reported in multiple papers (74-76).

After axotomy/nerve insult there is a significant upregulation of NOP receptor in the spinal cord as well as in the DRG) (77). Additionally, NOC is significantly increased in the DRG (77). Furthermore, NOC $(73,81-$ $85)$ and other NOP receptor agonists $(71,82,86)$ may inhibit allodynia and/or hyperalgesia.

\section{Opioid Analgesic Agents for Neuropathic Pain}

Multiple opioids have been successfully utilized to treat NP including morphine (4), methadone (4), hydromorphone (12), levorphanol (8), and transdermal fentanyl (87). However, "all opioids are not created equally." Although definitive evidence does not exist, it is conceivable that some opioids (or opioid-like analgesic agents) may be relatively more effective at providing analgesia for patients with NP than others. Agents that may conceivably be particularly effective against NP may include: oxycodone, methadone, buprenorphine, tapentadol, and tramadol.

\section{Mor Splice Variants}

The importance of different splice variants cannot be overstated. Different splice variants can lead to entirely different effects. This is well illustrated by examining the molecular basis of opioid-induced itch. Two MOR (MOR) splice isoforms (MOR1 and MOR1D) have distinct $C$ termini, are expressed in mutually exclusive subsets of spinal cord neurons, and mediate spinal opioid-induced analgesia and itch, respectively. MOR1D interacts with gastrin-releasing peptide receptor (GRPR) (a $G$ protein-coupled receptor) in a unidirectional manner, with resultant GRPR stimulation to specifically mediate opioid-induced itching (88). The MOR1D-GRPR interaction mediates opioid-induced itching alone and does not contribute to opioid-induced analgesia. Furthermore, blocking MOR1D-GRPR heterodimerization may be a highly specific way to attenuate opioidinduced itch (87). It is conceivable that a specific MOR splice isomer interaction with a specific $G$ protein-coupled receptor (GPCR)/GPCR subunit may be beneficial for alleviating NP (89).

\section{G-Protein Subtypes}

The G transducer proteins Gi, Go, Gz, Gll and Gq classes are involved in the supraspinal analgesic effects of opioids. Impairment of $\mathrm{Gi} 2 \alpha, \mathrm{Gi} 3 \alpha$, and $\mathrm{Gz} \alpha$ function led to weaker analgesic responses to various opioids (e.g., methadone, buprenorphine) (90). SánchezBlázquez and colleagues (90) demonstrated that the administration of an oligodeoxynucleotides (ODN) to the PTX-sensitive Gi2 $\alpha$ subunits or to the PTX-insensitive $\mathrm{Gz}$ subunits was followed by a significant decrease in the antinociceptive potency of all the agonists under study. Though the impairment of Gi1 $\alpha$ function did not change the response of the mice to morphine and buprenorphine, it did lead to a decrease in the effect of methadone. The antisense probe to $\mathrm{Gi} 3 \alpha$ subunits reduced the antinociception of methadone and buprenorphine while morphine-induced antinociception was unchanged (90).

The supraspinal antinociceptive effects of methadone were greatly reduced by the administration of the ODNs directed to both Go1 $\alpha$ or G11 $\alpha$ subunits, while neither buprenorphine nor morphine antinociception was influenced by these treatments. Further, the antisense ODNs to Go2 $\alpha$ and Gq $\alpha$ subunit-mRNAs also produced dissimilar effects; buprenorphine-induced antinociception was reduced while the activity of methadone, as well as that exhibited by morphine, was unaltered (90).

It is possible that the interaction of different opioids with different G-protein subtypes may be partly responsible for the different analgesic responses of different opioids in different individuals and/or different pain states. Therefore, if one opioid agent does not provide adequate analgesia it is still worthwhile proceeding with a trial of a different opioid agent (preferably one with different G-protein interactions).

In particular, it is conceivable that the interaction/ participation of Go- and Gq11-proteins may lead to analgesic effects that are especially beneficial in certain NP states (89). Methadone and buprenorphine interact with these G-protein subtypes but morphine does not. Methadone and buprenorphine are also significantly different from each other. Buprenorphine and methadone demonstrate a significant difference in activation of G proteins; G-i1 $\alpha$, G-01, and G- I1 $\alpha$ are necessary for methadone-induced analgesia, but not buprenorphineinduced analgesia; whereas, buprenorphine-induced analgesia requires $\mathrm{G}-\mathrm{o} 2 \alpha$ and $\mathrm{G}-\mathrm{q} \alpha$ but methadone does not (90). (Table 1). 
Opioids and Neuropathic Pain

Table 1. Different G-protein subtype interactions of different opioids [data from Sánchez-Blázquez 2001 (89)]

\begin{tabular}{|c|c|c|c|c|c|}
\hline \multirow[b]{2}{*}{ Opioid } & \multicolumn{5}{|c|}{ G-Protein Subtype } \\
\hline & $\mathrm{G}_{\mathrm{i}}$ & $\mathrm{G}_{\mathrm{o}}$ & $\mathrm{G}_{\mathrm{z}}$ & $\mathrm{G}_{\mathrm{q}}$ & $\mathrm{G}_{\|}$ \\
\hline Morphine & $\mathrm{G}_{\mathrm{i} 2}$ & --- & $\mathrm{G}_{\mathrm{z}}$ & --- & --- \\
\hline Methadone & $\begin{array}{l}\mathrm{G}_{\mathrm{i} 1} \\
\mathrm{G}_{\mathrm{i} 2} \\
\mathrm{G}_{\mathrm{i} 3}\end{array}$ & $\mathrm{G}_{\mathrm{ol}}$ & $\mathrm{G}_{\mathrm{z}}$ & --- & $\mathrm{G}_{\|}$ \\
\hline Buprenorphine & $\begin{array}{l}\mathrm{G}_{\mathrm{i} 2} \\
\mathrm{G}_{\mathrm{i} 3}\end{array}$ & $\mathrm{G}_{02}$ & $\mathrm{G}_{z}$ & $\mathrm{G}_{\mathrm{q}}$ & -- \\
\hline
\end{tabular}

Sánchez-Blázquez P, Gómez-Serranillos P, Garzón J. Agonists determine the pattern of G-protein activation in mu-opioid receptor-mediated supraspinal analgesia. Brain Res Bull 2001; 54:229-235.

\section{Specific Opioid Agents/Opioid-Like Analgesic Agents [Olas]}

\section{Oxycodone}

The oxycodone (6-deoxy-7,8-dehydro-14-hydroxy3-0-methyl-6-oxomorphine) molecule consists of 2 planar and 2 aliphatic rings. Important groups for analgesic actions of the phenanthrene are linked to positions $\mathrm{C} 3, \mathrm{C} 6$, and $\mathrm{N}(91)$.

Oxycodone is a semisynthetic opioid analgesic derived from the natural alkaloid thebaine and has been in clinical use since 1971. Oxycodone has a high oral bioavailability and when administered orally seems to provide potent analgesic effects "in the same ballpark" as oral morphine. Like other opioids, the analgesic effect of oxycodone is mediated through the activation at the $\mu$-opioid receptor, although its affinity and intrinsic activity to -opioid receptor is lower than morphine (92, 93).

The affinity of oxycodone to the $\mu$-opioid receptor is $>20$ times less than that of morphine (94). Also, the concentration of oxycodone needed to activate the Gprotein as measured by the [35S]GTPCS agonist-stimulated binding is 3-8 times higher than that of morphine (94-96). In spite of this, oxycodone is equally potent to morphine after systemic administration when differences in bioavailability are taken in account (97-99).

Narita and colleagues (93) compared the pharmacological profiles of morphine and oxycodone under a rodent model NP -like state. There were no significant differences in spinal or supraspinal antinociception of morphine and oxycodone between sham operation and nerve ligation. Moreover, either morphine- or oxycodone-induced increase in guanosine-5'-o-(3-thio) triphosphate ([35S]GTPgammaS) binding in the spinal cord, thalamus in sciatic nerve-ligated mice was similar to that in sham-operated mice. Antinociception induced by subcutaneous (s.c).,define intrathecal, or intracerebroventricular injection of the morphine metabolite morphine-6-glucuronide (M-6-G) was significantly decreased by sciatic nerve ligation. Furthermore, the increase in the G-protein activation induced by M-6-G was eliminated in sciatic nerve ligation (93). These findings provide further evidence that oxycodone shows a significant antinociceptive effect under an NP -like state. Furthermore, the reduction in G-protein activation induced by M-6-G may, at least in part, contribute to the suppression of the antinociceptive effect produced by morphine under an NP -like state (93).

Largent-Milnes and colleagues (100) investigated whether Oxytrex (oxycodone with an ultra-low dose of naltrexone) alleviates mechanical and thermal hypersensitivities in an animal model of NP over a period of 7 days, given locally or systemically (100). Chronic opioid administration may lead to a shift in $\mu$-opioid receptor (MOR)-G protein coupling from $G(\mathrm{i} / \mathrm{o})$ to $\mathrm{G}(\mathrm{s})$ that can be prevented by co-treatment with an ultra-low dose opioid antagonist. Using lumbar spinal cord tissue from rats with $L(5) / L(6)$ spinal nerve ligation , Largent-Milnes et al demonstrated that SNL injury induces MOR linkage to $G(s)$ in the damaged (ipsilateral) spinal dorsal horn. This MOR-G(s) coupling occurred without changing $\mathrm{G}(\mathrm{i} / \mathrm{o})$ coupling levels and without changing the expression of MOR or G alpha proteins (100). Repeated spinal oxycodone exacerbated the spinal nerve ligation -induced MOR-G(s) coupling, whereas ultra-low-dose NTX cotreatment slightly but significantly attenuated this $\mathrm{G}(\mathrm{s})$ coupling. Either spinal or oral administration of oxycodone plus ultra-low-dose NTX markedly enhanced the reductions in allodynia and thermal hyperalgesia produced by oxycodone alone and minimized tolerance to these effects (100). 
In addition to $\mu$-opioid receptors, oxycodone shows moderate affinity to morphine-insensitive component (probably putative $\kappa 2 b$-opioid receptor) (101). There is evidence to suggest that each opioid receptor can form a heterodimer with any other opioid receptor. Heterodimerization of opioid receptors results in changes in the pharmacology of the receptor (102). It has been proposed that the putative $\kappa 2$-opioid receptor represents the heterodimerization of $\kappa-$ and $\delta$-opioid receptors (103).

This additional mechanism of action has been proposed as a potential benefit, which may make oxycodone well suited for treating NP (39). However, it appears that oxycodone is predominantly a mu-opioid agonist in producing analgesia, respiratory depression, euphoria, and addiction, which are all typical mu-opioid receptor mediated effects. It also tends to cause less dysphoria than morphine and it does not exhibit diuretic properties which is another $\kappa$-opioid receptor mediated effect (102). Preliminary data, of Minami and colleagues (104), however, suggested that the antinociceptive effects of three opioids (oxycodone, fentanyl, morphine) in the femur bone cancer (FBC) model were completely antagonized by a $\mu$-opioid receptor antagonist, $\beta$-FNA, and not by a $\kappa$-opioid receptor antagonist, nor-BNI . Therefore, they concluded the $\mu$ - opioid receptors appeared to mediate the analgesic effects of all three opioids (104). Kato et al (105), using the same FBC model, unlike morphine and fentanyl, oxycodone relieved not only ongoing pain, but also ambulatory and $\mathrm{NP}$, and that the analgesic profile of oxycodone could be different from that of either morphine or fentanyl .

Minami and colleagues (104) examined the effects of three opioids (morphine, oxycodone, fentanyl) in a sciatic nerve ligation (SNL) model of NP, and found that oxycodone was the most effective, producing an antinociceptive effect without affecting the withdrawal threshold of sham-treated animals .

It has been reported that several receptors are known to couple to multiple effectors to initiate downstream signals and that different ligands can promote distinct relative efficacies in the downstream signals, resulting in a ligand-dependent efficacy profile (106). Another possibility is that different types of the $\mu$-opioid receptor splice variants are responsible for different efficacy of each opioid. Several $\mu$-opioid receptor splice variants have been identified (107), and it is possible that each splice variant may utilize a different downstream signaling pathway or are expressed in different anatomical regions to exhibit a distinctive pharmaco- logical profile. Moreover, heterodimerization of the $\mu$-opioid receptor and other receptors is another possible mechanism for the different opioid efficacy since the intracellular signals including a coupled G-protein can be affected by receptor dimerization $(108,109)$.

Research indicates that a major difference between oxycodone and morphine could be in the passage of these opioids through the blood-brain barrier (BBB). Both drugs appear to be equally hydrophilic, but oxycodone seems to be actively transported through the BBB by a transporter that has not been identified $(110,111)$. The concentrations of oxycodone are higher in the brain compared with the plasma, whereas the reverse is true with morphine.

Watson and Babul (112) conducted a randomized trial of oxycodone for the treatment of postherpetic neuralgia. Pain intensity and pain relief were assessed daily, and steady (ongoing) pain, brief (paroxysmal) pain, skin pain (allodynia), and pain relief were recorded at weekly visits (112). Compared with placebo, oxycodone resulted in pain relief $(2.9+/-1.2$ versus $1.8+/-1.1$, $P=0.0001)$ and reductions in steady pain $(34+/-26$ versus $55+/-27 \mathrm{~mm}, P=0.0001)$, allodynia (32+/-26 versus $50+/-$ $30 \mathrm{~mm}, P=0.0004)$, and paroxysmal spontaneous pain $(22+/-24$ versus $42+/-32 \mathrm{~mm}, P=0.0001)$ (112). Global effectiveness, disability, and masked patient preference also all showed superior scores with oxycodone relative to placebo (112). Watson and Babul (112) concluded that controlled-release oxycodone is an effective analgesic for the management of steady pain, paroxysmal spontaneous pain, and allodynia, which frequently characterize postherpetic neuralgia .

Wörz and colleagues (113) performed 2 postmarketing studies in Germany involving 603 patients with NP treated with controlled-release oxycodone (mean daily oxycodone dose was slightly more than $40 \mathrm{mg} /$ day). Mean pain intensity decreased from $>6$ initially to about 4 after one week, and under 3 after 3 weeks of treatment. Impairment, quality of life and performance (daily activities, mood, sleep quality and enjoyment of life) improved significantly (113).

In 2003, 2 randomized controlled-trials (RCTs) $(6,7)$ of controlled-release oxycodone for NP (both for painful diabetic neuropathy) concluded that controlled-release oxycodone is effective and safe for the management of NP.

Ong (114) conducted a retrospective observational study of controlled-release of Oxycodone in patients with moderate to severe NP despite treatment with anticonvulsants and antidepressants. Thirty-five patients 
had NP unrelated to cancer (average daily oxycodone dose $=25 \mathrm{mg}$ ) and 32 patients had NP secondary to cancer (average daily oxycodone dose $=40 \mathrm{mg}$ ) (114). The improvement in pain score seen in both groups supported the notion that oxycodone may be well suited for the treatment of NP.

In 2008 Núñez Olarte (115) performed a nonsystematic, yet comprehensive review of the literature and found 3 RCTs and one open-label study on oxycodone and NP which he concluded supported a significant role for oxycodone for neuropathic cancer pain .

\section{Tramadol}

Tramadol, a centrally acting analgesic available as both immediate release (IR) and extended release (ER) formulations, is structurally related to codeine and morphine, consists of 2 enantiomers, both of which contribute to analgesic activity via different mechanisms (116). (+)-Tramadol and the metabolite (+)-Odesmethyl-tramadol (M1) are agonists of the mu opioid receptor. (+)-Tramadol inhibits serotonin reuptake and (-)-tramadol inhibits norepinephrine reuptake, enhancing inhibitory effects on pain transmission in the spinal cord (116).

Tramadol has a better potency ratio relative to morphine in NP than in nociceptive pain models (117). The doses of drug that were calculated to result in $50 \%$ pain inhibition (ED[50]) for tramadol and morphine were 2.1 and $0.9 \mathrm{mg} / \mathrm{kg}$, respectively, in $\mathrm{CCl}$ rats and 4.3 and $3.7 \mathrm{mg} / \mathrm{kg}$, respectively, in SNL rats (117). In the tail-flick assay of acute nociception, the potency of the 2 drugs differed markedly, as seen by $\operatorname{ED}(50)$ values of 5.5 and $0.7 \mathrm{mg} / \mathrm{kg}$ intravenously for tramadol and morphine, respectively. Accordingly, the analgesic potency ratio (ED[50] tramadol/ED[50] morphine) of both compounds differed in neuropathic (potency ratio $2.3 \mathrm{in} \mathrm{CCl}$ and 1.2 in SNL) and nociceptive pain models (potency ratio 7.8), suggesting a relative increase in potency of tramadol in NP compared with nociceptive pain (117).

Thus, it appears that tramadol, likely due to its actions of inhibiting the reuptake of serotonin and norepinephine, may be useful for the treatment of NP. Although clinical investigative results exist to support the effectiveness of tramadol for relief of NP, tramadol has not been shown to be better than any other opioids/OLAs at alleviating NP. Harati and colleagues (118) conducted a placebo-controlled, double-blind trial that showed tramadol was effective and safe in treating the pain of diabetic neuropathy . Harati et al (119) also evaluated the efficacy and safety of trama- dol in a 6-month open extension, following a 6-week double-blind randomized trial (118). They concluded that tramadol safely provides long-term relief of the pain of diabetic neuropathy. Freeman and colleagues (120) conducted a randomized study of tramadol/acetaminophen versus placebo in painful diabetic peripheral neuropathy. Tramadol/acetaminophen was more effective than placebo and was well tolerated in the management of painful DPN (120). They identified 6 eligible trials, 4 comparing tramadol with placebo, one comparing tramadol with clomipramine, and one comparing tramadol with morphine. In 2006, Hollingshead and colleagues (121) performed a Cochrane review on tramadol for NP. All 4 trials comparing tramadol with placebo showed a significant reduction in NP with tramadol. Three of the trials which compared tramadol to placebo (total 269 participants) were combined in a meta-analysis. The number needed to treat with tramadol compared to placebo to reach at least $50 \%$ pain relief was 3.8 (95\% confidence interval 2.8 to 6.3 ). There were insufficient data to draw conclusions about the effectiveness of tramadol compared to either clomipramine or morphine. One trial considered subcategories of NP. It found a significant therapeutic effect of tramadol of aresthesiaallodynia, and touch-evoked pain. Numbers needed to harm were calculated for side effects resulting in withdrawal from the placebo controlled trials. Three trials provided these data, and the combined number needed to harm was 8.3 (95\% confidence interval 5.6 to 17) (121). Hollingshead et al (121) concluded that tramadol is an effective treatment for NP. Tramadol was also found to provide effective analgesia in the treatment of neuropathic cancer pain from a 2007 randomized, double-blind, placebo-controlled study (122) as well as in the treatment of NP after spinal cord injury from a 2009 randomized, double-blind, placebo-controlled trial (123).

\section{Tapentadol}

Tapentadol is a novel centrally acting analgesic, initially formulated as an immediate-release preparation. It is a potent Schedule II analgesic approved for use by the US Food and Drug Administration (FDA) in 2009. In 2011, the FDA approved the extended-release formulation. Tapentadol extended release is available as 50 , $100,150,200$, and $250 \mathrm{mg}$ tablets with a recommended interval between dosing of about 12 hours. Tapentadol immediate-release is available as 50,75 , and $100 \mathrm{mg}$ tablets and provides 4-6 hours of analgesia. Tapentadol immediate-release was shown to provide analge- 
sia comparable with that of 10-15 mg of immediaterelease oxycodone in patients recovering from dental extraction pain and pain following bunionectomy. The controlled release formulation provides a 12-hour duration of activity, as well as the convenience and analgesic uniformity associated with twice per day dosing. It was also as effective as oxycodone in patients presenting with chronic osteoarthritis pain and chronic low back pain (124). Of importance in the comparator trials was the finding that patients treated with tapentadol had a lower incidence of adverse gastrointestinal events, including nausea, vomiting, and constipation, than those treated with oxycodone.

Tapentadol produces potent analgesic effects via its dual mechanism of action, i.e., mu opioid receptor agonism and norepinephrine reuptake inhibition. In animal models, tapentadol behaves as a weak opioid agonist, with 50 times less affinity than morphine for the mu receptor (124). Tapentadol exists as a single active enantiomer and is metabolized mainly by O-glucuronidation. Its principal metabolite is inactive, having no affinity for the mu opioid receptor or the norepinephrine transporter. Because the analgesic activity of tapentadol is limited to the primary molecule, no enzymes are needed to convert it to an active metabolite, as is the case for tramadol and codeine (124).

Tapentadol, but not morphine, selectively inhibits disease-related thermal hyperalgesia in a mouse model of diabetic NP (125). Tapentadol was more potent than morphine against heat hyperalgesia, with ED (50) (minimal effective dose) values of 0.32 (0.316) and 0.65 (1) $\mathrm{mg} / \mathrm{kg}$, respectively. Christoph and colleagues (125) hypothesized that this superior efficacy profile of tapentadol for NP is due to simultaneous activation of MOR and inhibition of NA reuptake (125).

Schröder and colleagues (126) analyzed the contribution of opioid and monoaminergic mechanisms to the activity of tapentadol in rat models of nociceptive and NP (126). Antinociceptive efficacy was inferred from tail withdrawal latencies of experimentally naive rats using a tail flick test. Antihypersensitive efficacy was inferred from ipsilateral paw withdrawal thresholds toward an electronic von Frey filament in a spinal nerve ligation model of monoNP. Tapentadol showed clear antinociceptive and antihypersensitive effects (>90\% efficacy) with median effective dose (ED(50)) values of 3.3 and $1.9 \mathrm{mg} / \mathrm{kg}$, respectively. While the antinociceptive $\mathrm{ED}(50)$ value of tapentadol was shifted to the right 6.4 -fold by naloxone $(21.2 \mathrm{mg} / \mathrm{kg})$ and only 1.7 -fold by yohimbine $(5.6 \mathrm{mg} / \mathrm{kg})$, the antihypersensi- tive $E D(50)$ value was shifted to the right 4.7 -fold by yohimbine $(8.9 \mathrm{mg} / \mathrm{kg})$ and only 2.7 -fold by naloxone $(5.2 \mathrm{mg} / \mathrm{kg})(126)$. Activation of both mu-opioid receptors and alpha2-adrenoceptors contribute to the analgesic effects of tapentadol. The relative contribution is, however, dependent on the particular type of pain, as mu-opioid receptor agonism predominantly mediates tapentadol's antinociceptive effects, whereas noradrenaline reuptake inhibition predominantly mediates its antihypersensitive effects (126).

Further support of the inhibition of norepinephrine reuptake being a major factor in tapentadol's effects on NP was seen in a rat model (127). Bee and colleagues (127) performed a series of in vivo electrophysiological tests in spinal nerve ligated and shamoperated rats to show that systemic tapentadol (1 and $5 \mathrm{mg} / \mathrm{kg}$ ) dose-dependently reduced evoked responses of spinal dorsal horn neurones to a range of peripheral stimuli, including brush, punctate mechanical and thermal stimuli. They also showed that spinal application of the selective (2)-adrenoceptor antagonist atipamezole, or alternatively the mu-opioid receptor antagonist naloxone, produced near complete reversal of tapentadol's inhibitory effects, which suggested not only that the spinal cord is the key site of tapentadol's actions, but in addition that no pharmacology other than muopioid receptor agonism norepinephrine reuptake inhibition (MOR-NRI) is involved in its analgesia. Moreover, according to the extent that the antagonists reversed tapentadol's inhibitions in sham and SNL rats, they suggested that there may be a shift from predominant opioid inhibitory mechanisms in control animals, to predominant noradrenergic inhibition in neuropathic animals (127).

Thus, it is conceivable that tapentadol, likely due to its actions of inhibiting the reuptake of norepinephrine, may be useful for the treatment of NP. Schwartz and colleagues (128) conducted a randomized-withdrawal, placebo-controlled trial investigating the safety and efficacy of tapentadol ER in patients with painful diabetic peripheral neuropathy . Although clinical evidence exists to support the effectiveness of tapentadol for relief of NP, tapentadol has not been shown to be better than any other opioids/OLAs at alleviating NP.

\section{Methadone}

Methadone is structurally dissimilar to standard alkaloid-type ringed-type structures (129). It is distinguished as being an open-chain (linear-type) molecule. In this sense it is most similar to propoxyphene. Metha- 
done contains a single chiral carbon atom and so exists as two enantiomers. The $1(\mathrm{R})$-enantiomer is primarily responsible for analgesia (130) with a 10-fold higher affinity for mu opioid receptors, and up to fifty times the analgesic activity of the $d(S)$-enantiomer (131). In the United States methadone is available in racemic form, a 50:50 mixture of 2 enantiomers, 1 (R)-enantiomer and $\mathrm{d}(\mathrm{S})$-enantiomer.

The I(R)-isomer is a potent pure full mu opioid- receptor agonist with low affinity for delta and kappa receptor (132). Multiple studies with cloned human receptors and with mu knock-out mice with full delta receptors show no significant effective methadone agonist action at delta opioid receptors (133). The $d(S)$ enantiomer, although relatively inactive at the mu opioid receptor, functions as a modest non-competitive $\mathrm{N}$-methyl-d-aspartate (NMDA) antagonist and also prevents the reuptake of 5-hydroxytryptamine and norepinephrine (134). Because of the different properties of the methadone enantiomers, they exhibit different treatment profiles in different pain models. Specifically, in the case of nerve injury pain, I(R)-methadone has been shown to yield greater anti-allodynia action when compared against morphine, oxycodone, d(S)-methadone, dl(SR)-methadone [racemic] (135). Therefore, it has been proposed that methadone may be an especially useful as an analgesic in NP (5, 136-139). Additionally, since N-methyl-D-aspartate receptor antagonist activity may also reverse opioid tolerance, methadone may also function to ameliorate this phenomenon $(140,141)$.

Lemberg and colleagues (135) studied the effects of the commonly used mu-opioid receptor agonists morphine, oxycodone, methadone and the enantiomers of methadone in thermal and mechanical models of acute pain and in the spinal nerve ligation model of NP in rats. In the spinal nerve ligation model of NP, subcutaneous administration of morphine, oxycodone, methadone and I-methadone had anti-allodynic effects in tests of mechanical and cold allodynia. I-methadone showed the strongest anti-allodynic effect of the tested drugs. d-methadone was inactive in all tests (135). Lemberg et al (135) suggested that I(R)-methadone should be studied for NP in humans .

Pelissier and colleagues (142) studied the antinociceptive synergy resulting from the combination of opioid receptor agonists and $\mathrm{N}$-methyl-D-aspartate (NMDA) receptor antagonists on NP, an isobolographic analysis of equianalgesic combinations of ketamine with methadone or morphine was performed in rats with mononeuropathy produced by placing four con- strictive ligatures around the common sciatic nerve. Combinations produced synergy of a supra-additive nature in the neuropathic paw, but only additive antinociception in the normal paw. The ketamine/methadone combination was more effective to produce antinociception in the neuropathic paw than was the ketamine/ morphine association, as revealed by the lower ED25. The results indicate supra-additive synergy between NMDA receptor antagonists and opioids, especially methadone, to produce antinociception in experimental neuropathy (142).

Morley and colleagues (5) conducted a doubleblind randomized controlled crossover trial comparing the analgesic effects of low doses of methadone to placebo in the management of NP. In this study 18 patients with a range of chronic NP syndromes which had responded poorly to standard analgesic approaches were randomly assigned to treatment periods of 20 days. In one period they received doses of either methadone 5 mg twice a day or placebo tablets on alternate evennumbered days. In the other period they received doses of either methadone $10 \mathrm{mg}$ twice per day or placebo tablets on alternate even-numbered days (5). Compared to placebo there was statistically significant improvement in analgesic outcomes with $20 \mathrm{mg}$ of methadone as compared to placebo (5).

Moulin and colleagues (139) published a case series of 50 consecutive noncancer pain patients who were seen at a tertiary care center who had failed multiple treatments including: antidepressants, anticonvulsants, opioids, and spinal cord stimulation who were treated with oral methadone for a variety of intractable NP states (139). Twenty-six patients (52\%) reported mild (4), moderate (15), marked (6) or complete (1) pain relief and continued on methadone at a mean maintenance dose of $159.8 \mathrm{mg} /$ day for a mean duration of 21.3 months. Fourteen patients $(28 \%)$ reported improved function on methadone relative to previous treatments (139).

Thus, it appears that methadone may be useful to combat NP due to its cooperative actions as an nmethyl-d-aspartate (NMDA) receptor antagonist and mu-opioid receptor agonist (143). Although anecdotal reports and published articles appear to support a role for methadone in alleviating NP $(136,138-140,144$, $145)$, there are not robust studies to show that it is a better analgesic for NP than other opioids/OLAs.

\section{Buprenorphine}

Buprenorphine is classified as a partial mu opioid agonist. It has been available in the US in parenteral 
formulation for pain and in sublingual tablets for opioid dependence. In 2011 the FDA has approved a transdermal formulation of buprenorphine, the Buprenorphine Transdermal System (BTS) (Butrans, Purdue Pharma, Stamford, CT) for treatment of moderate to severe chronic pain. Buprenorphine binds to the MOR with high affinity and slow dissociates from it (exhibiting prolonged receptor occupancy). In high doses it can act as a mu opioid antagonists. It is highly lipophilic and thus has a large volume of distribution. It tends to have a slow onset in the transdermal formulation (steady state achieved in about 3 days after initial application). Buprenorphine is hepatically metabolized (slowly cleared by liver via CYP2A4 and conjugases) to an active metabolite, norbuprenorphine, and excreted in the bile and urine. CYP3A4 accounts for about $65 \%$ of norbuprenorphine production and CYP2C8 for about 30\% (146). Minor metabolites include hydroxybuprenorphine and hydroxyl-norbuprenorphine (146). Its terminal half-life is roughly 26 hours. Although its predominant mechanisms of action are from being a mu-opioid receptor agonist, it may also exhibit actions as a partial/full agonist at the nociceptin opioid peptide (NOP) receptor (formerly called orphan-related ligand-1 receptor) and as a kappa opioid receptor agonist. It is conceivable that its action as a NOP agonist may be partially useful in certain NP states where NOP receptors may be upregulated.

Transdermal buprenorphine is available in three strengths delivering $5 \mu \mathrm{cg} / \mathrm{h}, 10 \mu \mathrm{cg} / \mathrm{h}$, or $20 \mu \mathrm{cg} / \mathrm{h}$. Patients who are opioid-naïve or taking an opioid equivalent of less than $30 \mathrm{mg} / \mathrm{d}$ of oral morphine should start with the $5 \mu \mathrm{cg} / \mathrm{h}$ strength. The maximum dose is 20 $\mu \mathrm{cg} / \mathrm{h}$ since higher doses may lead to QTc prolongation. It is worn for 7 days and then changed and it should not be cut. It should be applied to hairless skin at one of the 8 possible sites: upper outer arm, upper back, upper chest or the side of the chest (on right and left sides of the body). After 7 days, a new transdermal system should be applied to a new site thereby rotating sites. It is recommended to wait 21 days before re-using the same site. Heat from a heating pad or from a fever can increase absorption and serum concentration of the drug.

Kouya and colleagues (147) studied and compared the antinociceptive and anti-hyperalgesic effect of the partial opioid receptor agonist buprenorphine in normal and neuropathic rats (147). In normal rats, systemic buprenorphine produced dose-dependent antinociception on the hot plate test. In rats with peripheral nerve or spinal cord injury, buprenorphine markedly alleviated NP-related behaviors, including mechanical and cold allodynia/hyperalgesia at doses comparable to that producing antinociception. They suggested that buprenorphine may be a useful analgesic for treating NP (147).

It is possible that buprenorphine may show a distinct benefit in improving NP symptoms, which is considered a result of its specific pharmacological profile (148). The difference in analgesic responses between buprenorphine and other potent opioids may be due in part to different receptor $\mathrm{G}$ protein subtype interactions, or to its actions as a NOP agent.

Although anecdotal reports and published articles appear to support a role for buprenorphine in alleviating NP (148-153), there are no robust studies to show that it is a better analgesic for NP than other opioids/ OLAs.

\section{Opioid-induced Block of Sodium Channels}

One specific property of opioids which may contribute to the reason why some opioids may be particularly well-suited to provide analgesia in various neuropathic pain states may be the ability of various opioids to inhibit voltage-gated sodium channels. It is becoming appreciated that various different mu-opioid receptor agonists may differ significantly in their ability/potency to inhibit voltage-gated sodium channels as well as the individual sodium channel type that they inhibit (Table 2).

Meperidine appears to be the best studied opioid with respect to blocking voltage-gated sodium channels and it has been shown to block skeletal muscle sodium channel Nav 14 in a state-dependent manner via the local anesthetic (LA)-binding site (154). Leffler has shown that buprenorphine may also act as a potent local anesthetic and block voltage-gated sodium channels via the local anesthetic binding site (155). The potency of buprenorphine to block sodium channels is significantly higher than that of meperidine, lidocaine, or even bupivacaine when evaluated under identical experimental conditions (155-157). Buprenorphine blocked the generation of action potentials in isolated C-fibers with a higher potency and with slower onset and offset kinetics versus lidocaine (158). This is likely due in part to the high lipophilicity of buprenorphine (octanol: water partition coefficient roughly 2,000 versus about 200 for norbuprenorphine versus about 39 for meperidine), since lipophilicity is a major factor for potency of local anesthetics acting on sodium channels (159). 
Haeseler et al (160) found that sufentanil, fentanyl, and tramadol (but not morphine) block neuronal Nav 1.2 in a state dependent manner. Morphine does appear to block neuronal excitability in an opioid-receptor independent manner $(161,162)$; likely via tonic block of the tetrodotoxin (TTX) sensitive sodium channel Nav 1.7 (155).

\section{Potential Future Opioids/OLAs that may be particularly effective for neuropathic PAIN}

Amidino-TAPA is a tetrapeptide derivative of dermorphin (163), showing extremely high affinity and relatively high selectivity to $\mu$-opioid receptors (164). Unlike the many other mu-opioid receptor agonists the antiallodynic effects amidino-TAPA are not altered at all in the mouse model of nerve-injured neuropathy, perhaps in part because it may exhibit actions that may modulate dynorphin signaling in addition to its potent effects as a mu-opioid receptor agonist (39). The endogenous mu-opioid peptide, endomorphin-2 also may show potent anti-allodynic effect against NP (165). Amidino-TAPA and endormorphin-2, may be opioids/ OALs that are also well-suited potential future agents to combat NP.

RSA 504 and RSA 601 are novel bifunctional compounds developed to target NP by simultaneously acting as agonists at two distinct opioid receptors (mu and delta) and antagonizing cholecystokinin (CCK) receptors in the CNS (166). RSA 504 and RSA 601 demonstrate agonist activity in vitro and antihypersensitivity to mechanical and thermal stimuli in vivo using the spinal nerve ligation model of NP. Intrathecal administration of RSA 504 and RSA 601 did not demonstrate antinociceptive tolerance over 7 days of administration and
Table 2. Potency of opioids to inhibit Na+ Channels

\begin{tabular}{||l|c|c||}
\hline \multicolumn{1}{|c|}{ Opioid } & $\begin{array}{c}\text { Voltage-gated } \\
\text { Na+ Channel }\end{array}$ & $\begin{array}{c}\text { Rough Relative } \\
\text { Potency to Block } \\
\text { Na+ Channel }\end{array}$ \\
\hline Buprenorphine & Nav 1.4 & +++++ \\
\hline Meperidine & Nav 1.4 & ++++ \\
\hline Fentanyl & Nav 1.2 & +++ \\
\hline Sufentanil & Nav 1.2 & +++ \\
\hline Tramadol & Nav 1.2 & ++ \\
\hline Morphine & Nav 1.7 & + \\
\hline Remifentanil & -------- & -------- \\
\hline
\end{tabular}

did not display motor impairment or sedation using a rotarod (166). These compounds with $\delta$ and $\mu$ opioid agonist activity and CCK antagonist activity within one molecule may offer a novel therapeutic approach with efficacy for NP while lacking the side effects typically caused by conventional opioid therapies (166).

\section{Conclusion}

The evaluation and treatment of neuropathic pain is extremely challenging and complex. However, it appears that for the foreseeable future it will remain an art, since every individual patient is different, individual opioid analgesic agents are different, opioid receptors and their splice variants are different (and may produce different effects), G-protein subtypes are different and neuropathic pain states are different. A greater appreciation of these differences may help clinicians optimally manage disabling symptoms experienced by these patients "at the bedside."

\section{References}

1. Arnér S, Meyerson BA. Lack of analgesic effect of opioids on neuropathic and idiopathic forms of pain. Pain 1988; 33:1123.

2. Portenoy RK, Foley KM, Inturrisi CE. The nature of opioid responsiveness and its implication for neuropathic pain: New hypotheses derived from studies of opioid infusions. Pain 1990; 43:273-286.

3. Arnér $S$, Meyerson BA. Genuine resistance to opioids--fact or fiction? Pain 1991; 47:116-121.

4. Raja SN, Haythornthwaite JA, Pappagallo M, Clark MR, Travison TG, Sabeen S, Royall RM, Max MB. Opioids versus an- tidepressants in postherpetic neuralgia: 7 . A randomized, placebo-controlled trial. Neurology 2002; 59:1015-1021.

5. Morley JS, Bridson J, Nash TP, Miles JB, White S, Makin MK. Low-dose metha- 8 . done has an analgesic effect in neuropathic pain: A double-blind randomized controlled crossover trial. Palliat Med 2003; 17: 576-587.

6. Watson CP, Moulin D, Watt-Watson J, 9 Gordon A, Eisenhoffer J. Controlled-release oxycodone relieves neuropathic pain: A randomized controlled trial in painful diabetic neuropathy. Pain 2003; 105:71-78.
Gimbel JS, Richards P, Portenoy RK. Controlled-release oxycodone for pain in diabetic neuropathy: A randomized controlled trial. Neurology 2003; 60:927-934.

8. Rowbotham MC, Twilling L, Davies PS, Reisner L, Taylor K, Mohr D. Oral opioid therapy for chronic peripheral and central neuropathic pain. N Engl J Med 2003; 348:1223-1232.

Eisenberg E, McNicol ED, Carr DB. Efficacy and safety of opioid agnonists in the treatment of neuropathic pain of nonmalignant origin: Systematic review and meta-analysis of randomized controlled trials. JAMA 2005; 293:3043-3052. 
10. Eisenberg E, McNicol ED, Carr DB. Efficacy of mu-opioid agonists in the treatment of evoked neuropathic pain: Systematic review of randomized controlled trials. Eur J Pain 2006; 10:667-676.

11. Edwards RR, Haythornthwaite JA, Tella P, Max MB, Raja S. Basal heat pain thresholds predict opioid analgesia in patients with postherpetic neuralgia. Anesthesiology 2006; 104:1243-1248.

12. Moulin DE, Richarz U, Wallace M, Jacobs A, Thipphawong J Efficacy of the sustained-release hydromorphone in neuropathic pain management: pooled analysis of three open-label studies. J Pain Palliat Care Pharamcother 2010; 24:200-212.

13. Kalso E, Edwards JE, Moore RA, McQuay $\mathrm{HJ}$. Opioids in chronic non-cancer pain: Systematic review of efficacy and safety. Pain 2004; 112:372-380.

14. Smith HS. Opioids and neuropathic pain: Presented at the Capital District 2011 Pain Conference; July 2011; Albany, NY.

15. Mercadante S, Gebbia V, David F, Aiell F, Verna L, Casuccio A, Porzio G, Mangione $S$, Ferrera $P$. Tools for identifying cancer pain of predominantly neuropathic origin and opioid responsiveness in cancer patients. J Pain 2009; 10:594600.

16. Smith HS. Pain responsiveness to opioids: Central versus peripheral neuropathic pain. J Opioid Manag 2011; :391400.

17. Vassias I, Lecolle S, Vidal PP, de Waele C. Modulation of GABA receptor subunits in rat facial motoneuraons after axotomy. Brain Res Mol Brain Res 2005; 135:260-275.

18. Richardson PM, Miao T, Wu D, Zhang Y, Yeh J, Bo X. Responses of the nerve cell body to axotomy. Neurosurgery 2009; 65:A74-79.

19. Eleore L, Vassias I, Vidal PP, de Waele C Modulation of the glutamatergic receptors (AMOA and NMDA) and of glutamate vesicular transporter 2 in the rat facial nucleus after axotomy. Neuroscience 2005; 136:147-160.

20. Viscomi MT, Florenzano F, Conversi D, Bernardi G, Molinari M. Axotomy dependent purinergic and nitrergic coexpression. Neuroscience 2004; 123:393404.

21. Mika J, Obara I, Przewlocka B. The role of nociception and dynorphin in chronic pain: Implications of neuro-glial interaction. Neuropeptides 2011; 45:247-261.
22. Bian D, Nichols ML, Ossipov MH, Lai J, Porreca F. Characterization of the antiallodynic efficacy of morphine in a model of neuropathic pain in rats. Neuroreport 1995; 6:1981-1984.

23. deGroot JF, Coggeshall RE, Carlton SM The reorganization of mu opioid receptors in the rat dorsal horn following peripheral axotomy. Neurosci Lett 1997; 233:113-116.

24. Lee YW, Chaplan SR, Yaksh TL. Systemic and supraspinal, but not spinal, opiates suppress allodynia in a rat neuropathic pain model. Neurosci Lett 1995; 199:111114 .

25. Zurek JR, Nadeson R, Goodchild CS. Spinal and supraspinal components of opioid antinociception in streptozotocin induced diabetic neuropathy in rats. Pain 2001; 90:57-63.

26. Porreca F, Tang QB, Bian D, Riedl M, Elde R, Lai J. Spinal opioid mu receptor expression in lumbar spinal cord of rats following nerve injury. Brain Res 1998; 795:197-203.

27. Chen SR, Pan HL. Antinociceptive effect of morphine, but not mu opioid receptor number, is attenuated in the spinal cord of diabetic rats. Anesthesiology 2003; 99:1409-1414.

28. Chen SR, Sweigart KL, Lakoski JM, Pan $\mathrm{HL}$. Functional mu opioid receptors are reduced in the spinal cord dorsal horn of diabetic rats. Anesthesiology 2002; 97:1602-1608.

29. Narita $M$, Oe K, Kato $H$, Shibasaki $M$, Narita M, Yajima Y, Yamazaki M, Suzu$\mathrm{ki}$ T. Implication of spinal protein kinase $\mathrm{C}$ in the suppression of morphine-induced rewarding effect under a neuropathic pain-like state in mice. Neuroscience 2004; 125:545-551.

30. Mao J, Price DD, Phillips LL, Lu J, Mayer DJ. Increases in protein kinase $C$ gamma immunoreactivity in the spinal cord dorsal horn of rats with painful mononeuropathy. Neurosci Lett 1995; 198:7578.

31. Roberts RE, McLean WG. Protein kinase $C$ isozyme expression in sciatic nerves and spinal cords of experimentally diabetic rats. Brain Res 1997; 754:147-156.

32. Yajima $Y$, Narita M, Shimamura M, Narita M, Kubota C, Suzuki T. Differential involvement of spinal protein kinase $C$ and protein kinase $A$ in neuropathic and inflammatory pain in mice. Brain Res 2003; 992:288-293.

33. Niikura $K$, Narita $M$, Butelman ER, Kreek MJ, Suzuki T. Neuropathic and chronic pain stimuli downregulate central mu-opioid and dopaminergic transmission. Trends Pharmacol Sci 2010; 31:299-305.

34. Hoot MR, Sim-Selley LJ, Selley DE, Scoggins KL, Dewey WL. Chronic neuropathic pain in mice reduces $\mu$-opioid receptor-mediated G-protein activity in the thalamus. Brain Res 2011; 1406:1-7.

35. Rodríguez-Muñoz $M$, Sánchez-Blázquez $P$, Vicente-Sánchez A, Berrocoso E, Garzón J. The mu-opioid receptor and the NMDA receptor associate in PAG neurons: Implications in pain control. Neuropsychopharmacology 2011; In press.

36. Mao J, Price DD, Mayer DJ. Experimental mononeuropathy reduces the anti nociceptive effects of morphine: Implications for common intracellular mechanisms involved in morphine tolerance and neuropathic pain. Pain 1995; 61:353-364.

37. Narita M, Yajima Y, Aoki T, Ozaki S, Mizoguchi H, Tseng LF, Suzuki T. Up regulation of the TrkB receptor in mice injured by the partial ligation of the sciatic nerve. Eur] Pharmacol 2000; 40187190.

38. Yajima Y, Narita M, Usui A, Kaneko C, Miyatake M, Narita M, Yamaguchi T, Tamaki $\mathrm{H}$, Wachi H, Seyama Y, Suzuki T. Direct evidence for the involvement of brain-derived neurotrophic factor in the development of a neuropathic pain-like state in mice. J Neurochem 2005; 93:241242.

39. Mizoguchi $\mathrm{H}$, Watanabe $\mathrm{C}$, Yonezawa A, Sakurada S. New therapy for neuropathic pain. Int Rev Neurobiol 2009; 85:249260.

40. Mao J, Price, DD, Hayes RL, Lu J, and Mayer DJ. Differential roles of NMDA and non-NMDA receptor activation in induction and maintenance of thermal hyperalgesia in rats with painful peripheral mononeuropathy. Brain Res 1992; 598:271-278.

41. Sánchez-Blázquez $P$, Rodríguez-Muñoz M, Garzón J. Mu-opioid receptors transiently activate the Akt-nNOS pathway to produce sustained potentiation of PKC-mediated NMDAR-CaMKII signaling. PLoS One 2010; 5 :e11278.

42. Rodríguez-Muñoz M, de la Torre-Madrid $\mathrm{E}$, Sánchez-Blázquez $\mathrm{P}$, Wang JB, Garzón J. NMDAR-nNOS generated zinc recruits $\mathrm{PKCg}$ to the HINT1-RGS17 complex bound to the $C$ terminus of mu-opioid receptors. Cell Signal 2008; 20:1855-1864.

43. Rodríguez-Muñoz M, de la Torre-Ma- 
drid E, Sánchez-Blázquez P, Garzón J. NO-released zinc supports the simultaneous binding of Raf-1 and PKCg cysteine-rich domains to $\mathrm{HINT}$ p protein at the mu-opioid receptor. Antioxid Redox Signal 2011; 14:2413-2425.

44. Sánchez-Blázquez $\mathrm{P}$, Rodríguez-Muñoz M, de la Torre-Madrid E, Garzón J. Brain-specific Gaz interacts with Src tyrosine kinase to regulate mu-opioid receptor-NMDAR signaling pathway. Cell Signal 2009; 21:1444-1454.

45. Sánchez-Blázquez $\mathrm{P}$, Rodríguez-Muñoz $M$, Montero $C$, de la Torre-Madrid E, Garzón J. Calcium/calmodulindependent protein kinase II supports morphine antinociceptive tolerance by phosphorylation of glycosylated phosducin-like protein. Neuropharmacology 2008; 54:319-330.

46. Zalewski PD, Forbes IJ, Giannakis C, Cowled PA, Betts WH. Synergy between zinc and phorbol ester in translocation of protein kinase $C$ to cytoskeleton. FEBS Lett 1990; 273:131-134.

47. Garzón J, Rodríguez-Muñoz M, VicenteSánchez A, Bailón C, Martínez-Murillo R, Sánchez-Blázquez P. RGSZ2 binds to the $\mathrm{nNOS}$ PDZ domain to regulate muopioid receptor-mediated potentiation of the NMDAR-CaMKII pathway. Antioxid Redox Signal 2011; 15:873-887.

48. Kajander KC, Sahara Y, Ladarola MJ, Bennett GJ. Dynorphin increase in the dorsal spinal cord in rats with a painful peripheral neuropathy. Peptides 1990; 11:719-728.

49. Wang Z, Gardell LR, Ossipov MH, Vanderah TW, Brennan MB, Hochgeschwender U, Hruby VJ, Mala TP, Jr, Lai J, Porreca F. Pronociceptive actions of dynorphin maintain chronic neuropathic pain. J Neurosci 2001; 21:1779-1786.

50. Vanderah TW, Gardell LR, Burgess SE, Ibrahim M, Dogrul A, Zhong CM, Zhang ET, Malan TP, Jr., Ossipon MH, Lai J, Porreca F. Dynorphin promotes abnormal pain and spinal opioid antinociceptive tolerance. J Neurosci 2000; 20:7074-7079.

51. Hahm ET, Kim Y, Lee JJ, Cho YW. GABAergic synaptic response and its opioidergic modulation in periaqueductal gray neurons of rats with neuropathic pain. BMC Neurosci 2011; 12:41.

52. Hains BC, Saab CY, Klein JP, Craner MJ, Waxman SG. Altered sodium channel expression in second-order spinal sensory neurons contributes to pain after peripheral nerve injury. J Neurosci 2004; 24:4832-4839.
53. Yang L, Zhang FX, Huang F, Lu YJ, Li GD, Bao L, Xiao HS, Zhang X. Peripheral nerve injury induces trans-synaptic medication of channels, receptors and signal pathways in rat dorsal spin cord. Eur ] Neurosci 2004; 19:871-883.

54. Lei S, Dryden WF, Smith PA. Regulation of $\mathrm{N}$ - and L-type calcium channels in adult frog sympathetic ganglion $\mathrm{B}$ cells by nerve growth factor in vitro and in vivo. J Neurophysiol 1997; 78:3359-3370.

55. Petrov T, Shapiro Y, Baker C, Duff JP, Sanders EJ, Gordon T, Smith PA. Peripheral target contact regulates $\mathrm{Ca} 2+$ channels in the cell bodies of bullfrog sympathetic ganglion B-neurons. Auton Neurosci 2001; 89:74-85.

56. Chen $Y$, Balasubramanyan S, Lai AY, Todd KG, Smith PA. Effects of sciatic nerve axotomy on excitatory synaptic transmission in rat substantia gelatinosa. J Neurophysiol 2009; 102:3203-3215.

57. Baccei ML, Kocsis JD. Voltage-gated calcium currents in axotomized adult rat cutaneous afferent neurons. J Neurophysiol 2000; 83:2227-2238.

58. Cizkova D, Marsala J, Lukacova N, Marsala M, Jergova S, Orendacova J, Yaksh TL. Localization of N-type $\mathrm{Ca}+$ channels in the rat spinal cord following chronic constrictive nerve injury. Exp Brain Res 2002; 147:456-463.

59. Narita M, Nakajima M, Miyoshi K, Narita M, Nagumo Y, Miyatake M, Yajima Y, Yanagida K, Yamazaki M, Suzuki T. Role of spinal voltage-dependent calcium channel alpha 2 delta-1 subunit in the expression of a neuropathic painlike state in mice. Life Sci 2007; 8:20152024.

6o. Scott DA, Wright CE, Angus JA. Actions of intrathecal omega-conotoxins CVID, GVIA, MVILA, and morphine in acute and neuropathic pain in the rat. Eur J Pharmacol 2002; 451:279-286.

61. Connor M, Vaughan CW, Chieng B, Christie MJ. Nociceptin receptor coupling to a potassium conductance in rat locus coeruleus neurones in vitro. $\mathrm{Br} J$ Pharmacol 1996; 119:1614-1618.

62. Vaughan CW, Christie MJ. Increase by the ORL1 receptor (opioid receptorlikes) ligand, nociceptin, of inwardly rectifying $\mathrm{K}$ conductance in dorsal raphe nucleus neurones. $\mathrm{Br}$ J Pharmacol 1996; 117:1609-1611.

63. Meunier J, Mouledous L, Topham CM. The nociceptin (ORL1) receptor: Molecular cloning and functional architecture. Peptides 2000; 21:893-900.
64. Nothacker HP, Reinscheid RK, Mansour A, Henningsen RA, Ardati A, Monsma FJ, Watson SJ, Civelli O. Primary structure and tissue distribution of the orphanin FQ precursor. Proc Natl Acad Sci USA 1996; 93:8677-8682.

65. Reinscheid RK, Nothacker HP, Bourson A, Ardati A, Henningsen RA,. Bunzow JR, Grandy DK, Langen $\mathrm{H}$, Monsma FJ, Civelli O. Orphanin FQ: A neuropeptide that activates an opioidlike $G$ proteincoupled receptor. Science 1995; 270:792794.

66. Reinscheid RK, Higelin J, Henningsen RA, Monsma FJ, Civelli O. Structures that delineate orphanin FQ and dynorphin A pharmacological selectivities. J Biol Chem 1998; 273:1490-1495.

67. Boom A, Mollereau C, Meunier JC, Vassart G, Parmentier M, Vanderhaeghen J, Schiffmann SN. Distribution of the nociceptin and nocistatin precursor transcript in the mouse central nervous system. Neuroscience 1999; 91:991-1007.

68. Houtani T, Nishi M, Takeshim H, Nukada T, Sugimoto T. Structure and regional distribution of nociceptin/orphanin FQ precursor. Biochem Biophys Res Commun 1996; 219:714-719.

69. Lapalu S, Moisand C, Mazarguil H, Cambois G, Mollereau C, Meunier JC. Comparison of the structure-activity relationships of nociceptin and dynorphin A using chimeric peptides. FEBS Lett 1997; 417:333-336.

70. Meunier JC, Mollereau C, Toll L, Suaudeau C, Moisand C, Alvinerie P, Butour JL, Guillemot JC, Ferrara P, Monsarrat B, Mazarguil H, Vassart G, Parmentier M, Costentin J. Isolation and structure of the endogenous agonist of opioid receptor-like ORL1 receptor. $\mathrm{Na}$ ture 1995; 377:532-535.

71. Abdulla FA, Smith PA. Axotomy reduces the effect of analgesic opioids yet increases the effect of nociceptin on dorsal root ganglion neurons. J Neurosci 1998; 18:9685-9694.

72. Bertorelli R, Corradini L, Rafiq K, Tupper J, Calò G, Ongini E. Nociceptin and the ORL-1 ligand [Pheipsi $\left(\mathrm{CH}_{2}-\mathrm{NH}\right) \mathrm{Gly}$ ] nociceptin $(1-13) \mathrm{NH}_{2}$ exert anti-opioid effects in the Freund's adjuvant-induced arthritic rat model of chronic pain. $\mathrm{Br}$ J Pharmacol 1999; 128:1252-1258.

73. Briscini L, Corradini L, Ongini E, Bertorelli R. Up-regulation of ORL-1 receptors in spinal tissue of allodynic rats after sciatic nerve injury. Eur J Pharmacol 2002; 447:59-65. 
74. Mika J, Schafer MK, Obara I, Weihe E, Przewlocka B. Morphine and endomorphin-1 differently influence pronociceptin/orphanin FQ system in neuropathic rats. Pharmacol Biochem Behav 2004; 78:171-178.

75. Obara I, Mika J, Schafer MK, Przewlocka B. Antagonists of the kappa-opioid receptor enhance allodynia in rats and mice after sciatic nerve ligation. $\mathrm{Br}$ J Pharmacol 2003; 140:538-546.

76. Wu HE, Schwasinger ET, Hong JS, Tseng LF. Pretreatment with antiserum against dynorphin, substance $P$, or cholecystokinin enhances the morphine-produced anti-allodynia in the sciatic nerve ligated mice. Neurosci Lett 2005; 386:46-51.

77. Obara I, Parkitna JR, Korostynski M, Makuch W, Kaminska D, Przewlocka B, Przewlocki R. Local peripheral opioid effects and expression of opioid genes in the spinal cord and dorsal root ganglia in neuropathic and inflammatory pain. Pain 2009; 141:283-291.

78. Chen Y, Sommer C. Nociceptin and its receptor in rat dorsal root ganglion neurons in neuropathic and inflammatory pain models: Implications on pain processing. J Peripher Nerv Syst 2006; 11:232-240.

79. Herradon G, Ezquerra L, Nguyen T, Wang C, Siso A, Franklin B, Dilorenzo L, Rossenfeld J, Silos-Santiago I, Alguacil LF. Noradrenergic and opioidergic alterations in neuropathy in different rat strains. Neurosci Lett 2008; 438:186-189.

8o. Mika J, Rojewska E, Makuch W, Przewlocka B. Minocycline reduces the injury-induced expression of prodynorphin and pronociceptin in the dorsal root ganglion in a rat model of neuropathic pain. Neuroscience 2010; 165:1420-1428.

81. Courteix C, Coudore-Civiale MA, Privat AM, Pelissier T, Eschalier A, Fialip J. Evidence for an exclusive antinociceptive effect of nociceptin/orphanin FQ, an endogenous ligand for the ORL1 receptor, in two animal models of neuropathic pain. Pain 2004; 110:236-245.

82. Obara I, Przewlocki R, Przewlocka B. Spinal and local peripheral antiallodynic activity of Ro64-6198 in neuropathic pain in the rat. Pain 2005; 116:17-25.

83. Yamamoto T, Nozaki-Taguchi N, Kimura S. Effects of intrathecally administered nociceptin, an opioid receptor-like (ORLI) receptor agonist, on the thermal hyperalgesia induced by unilateral constriction injury to the sciatic nerve in the rat. Neurosci Lett 1997; 224:107-110.
84. Yamamoto T, Ohtori S, Chiba T. Inhibitory effect of intrathecally administered nociceptin on the expression of Fos-like immunoreactivity in the rat formalin test. Neurosci Lett 2000; 284:155-158.

85. Xu X, Grass S, Hao J, Xu IS, Wiesenfeld-Hallin Z. Nociceptin/orphanin FQ in spinal nociceptive mechanisms under normal and pathological conditions. Peptides 2000; 21:1031-1036.

86. Khroyan TV, Polgar WE, Jiang F, Zaveri NT, Toll L. Nociceptin/orphanin FQ receptor activation attenuates antinociception induced by mixed nociceptin/orphanin FQ/mu-opioid receptor agonists. J Pharmacol Exp Ther 2009; 331:946-953.

87. Agarwal S, Polydefkis M, Block B, Haythornthwaite J, Raja SN. Transdermal fentanyl reduces pain and improves functional activity in neuropathic pain states. Pain Med 2007; 8:554-562.

88. Liu XY, Liu ZC, Sun YG, Ross M, Kim S, Tsai FF, Li QF, Jeffry J, Kim JY, Loh HH, Chen ZF. Unidirectional cross-activation of GRPR by MOR1D uncouples itch and analgesia induced by opioids. Cell 2011; 147:447-458.

89. Smith HS. Opioids and Neuropathic Pain. Presented at: The Capital District Pain Conference; September, 2011; Albany, NY.

90. Sánchez-Blázquez P, Gómez-Serranillos $P$, Garzón J. Agonists determine the pattern of G-protein activation in mu-opioid receptor-mediated supraspinal analgesia. Brain Res Bull 2001; 54:229-235.

91. Kalso E. Oxycodone. J Pain Symptom Manage 2005; 29:S47-56.

92. Lemberg KK, Kontinen VK, Siiskonen AO, Viljakka KM, Yli-Kauhaluoma JT, Korpi ER, Kalso EA. Antinociception by spinal and systemic oxycodone: Why does the route make a difference? In vitro and in vivo studies in rats. Anesthesiology 2006; 105:801-812.

93. Narita M, Nakamura A, Ozaki M, Imai S, Miyoshi K, Suzuki M, Suzuki T. Comparative pharmacological profiles of morphine and oxycodone under a neuropathic pain-like state in mice: Evidence for less sensitivity to morphine. Neuropsychopharmacology 2008; 33:1097-1112.

94. Peckham EM, Traynor JR. Comparison of the antinociceptive response to morphine and morphine-like compounds in male and female Sprague-Dawley rats. J Pharmacol Exp Ther 2006; 316:1195-1201.

95. Lalovic B, Kharasch E, Hoffer C, Risler L, Liu-Chen LY, Shen DD. Pharmacokinet- ics and pharmacodynamics of oral oxycodone in healthy human subjects: Role of circulating active metabolites. Clin Pharmacol Ther 2006; 79:461-479.

96. Thompson CM, Wojno H, Greiner E, May EL, Rice KC, Selley DE. Activation of $\mathrm{G}$-proteins by morphine and codeine congeners: Insight to the relevance of $\mathrm{O}$ - and $\mathrm{N}$-demethylated metabolites at I- and d-opioid receptors. J Pharmacol Exp Ther 2004; 308:547-554.

97. Heiskanen T, Kalso E. Controlled-release oxycodone and morphine in cancer related pain. Pain 1997; 73:37-45.

98. Kalso E, Pöyhiä R, Onnela P, Linko K, Tigerstedt I, Tammisto T. Intravenous morphine and oxycodone for pain after abdominal surgery. Acta Anaesth Scand 1991; 35:642-646.

99. Silvasti M, Rosenberg P, Seppälä T, Svartling N, Pitkänen M. Comparison of analgesic efficacy of oxycodone and morphine in postoperative intravenous patient-controlled analgesia. Acta Anaesth Scand 1998; 42:576-580.

10o. Largent-Milnes TM, Guo W, Wang HY, Burns LH, Vanderah TW. Oxycodone plus ultra-low-dose naltrexone attenuates neuropathic pain and associated mu-opioid receptor-Gs coupling. J Pain 2008; 9:700-713.

101. Nielsen CK, Ross FB, Lotfipour S, Saini KS, Edwards SR, Smith MT. Oxycodone and morphine have distinctly different pharmacological profiles: Radioligand binding and behavioural studies in two rat models of neuropathic pain. Pain 2007; 132:289-300.

102. Kalso E. How different is oxycodone from morphine? Pain 2007; 132:227-228.

103. Devi LA. Heterodimerization of G-protein-coupled receptors: Pharmacology, signaling and trafficking. Trends Pharmacol Sci 2001; 22:532-537.

104. Minami K, Hasegawa $M$, Ito $H$, Nakamura A, Tomii T, Matsumoto M, Orita $S$, Matsushima S, Miyoshi T, Masuno K, Torii M, Koike K, Shimada S, Kanemasa T, Kihara T, Narita M, Suzuki T, Kato A. Morphine, oxycodone, and fentanyl exhibit different analgesic profiles in mouse pain models. J Pharmacol Sci 2009; 111:60-72.

105. Kato A, Minami K, Ito H, Tomii T, Matsumoto $M$, Orita S, Kihara T, Narita M, Suzuki T. Oxycodone-induced analgesic effects in a bone cancer pain model in mice. Oncology 2008; 74:55-60.

106. Galandrin S, Oligny-Longpre G, Bouvier $M$. The evasive nature of drug efficacy: 
Implications for drug discovery. Trends Pharmacol Sci 2007; 28:423-430.

107. Pan YX, Xu J, Moskowitz HS, Xu M, Pasternak GW. Identification of four novel exon 5 splice variants of the mouse $\mu$-opioid receptor gene: Functional consequences of C-terminal splicing. $\mathrm{Mol}$ Pharmacol 2005; 68:866-875.

108. Hojo M, Sudo $Y$, Ando $Y$, Minami K, Takada M, Matsubara T, Kanaide $M$, Taniyama K, Sumikawa K, Uezono Y. $\mu$-Opioid receptor forms a functional heterodimer with cannabinoid $\mathrm{CB} 1$ receptor: Electrophysiological and FRET assay analysis. J Pharmacol Sci 2008; 108:308-319.

109. Hasbi A, Nguyen T, Fan T, Cheng R, Rashid A, Alijaniaram A, Rasenick MM, O'Dowd BF, George SR. Trafficking of preassembled opioid $\mu-\delta$ heterooligomer-Gz signaling complexes to the plasma membrane: Coregulation by agonists. Biochemistry 2007; 46:1299713009.

110. Boström E, Simonsson USH, Hammarlund-Udenaes $M$. In vivo blood-brain barrier transport of oxycodone in the rat: Indications for active influx and implications for pharmacokinetics/pharmacodynamics. Drugs Metab Dispos 2006; 34:1624-1631.

111. Bostrom E, Hammarlund-Udenaes M,Simonsson US. Blood-brain barrier transport helps to explain discrepancies in in vivo potency between oxycodone and morphine. Anesthesiolog. 2008; 108:495-505.

112. Watson CP, Babul N. Efficacy of oxycodone in neuropathic pain: A randomized trial in postherpetic neuralgia. Neurology 1998; 50:1837-1841.

113. Wörz R, Frank M, Achenbach U. Controlled-release oxycodone--a therapeutic option for severe neuropathic pain. Two multicenter observational studies [in German]. MMW Fortschr Med 2003; 145:71-76.

114. Ong EC. Controlled-release oxycodone in the treatment of neuropathic pain of nonmalignant and malignant causes. Oncology 2008; 74:72-75.

115. Núñez Olarte JM. Oxycodone and the challenge of neuropathic cancer pain: $\mathrm{A}$ review. Oncology 2008; 74:83-90.

116. Grond S, Sablotzki A. Clinical pharmacology of tramadol. Clin Pharmacokinet 2004; 43:879-923.

117. Christoph T, Kögel B, Strassburger W, Schug SA. Tramadol has a better potency ratio relative to morphine in neuro- pathic than in nociceptive pain models. Drugs RD 2007; 8:51-57.

118. Harati $Y$, Gooch C, Swenson M, Edelman S, Greene D, Raskin P, Donofrio P, Cornblath D, Sachdeo R, Siu CO, Kamin $M$. Double-blind randomized trial of tramadol for the treatment of the pain of diabetic neuropathy. Neurology 1998; 50:1842-1846.

119. Harati Y, Gooch C, Swenson M, Edelman SV, Greene D, Raskin P, Donofrio P, Cornblath D, Olson WH, Kamin M. Maintenance of the long-term effectiveness of tramadol in treatment of the pain of diabetic neuropathy. J Diabetes Complications 2000; 14:65-70.

120. Freeman R, Raskin P, Hewitt DJ, Vorsanger GJ, Jordan DM, Xiang J, Rosenthal NR; CAPSS-237 Study Group. Randomized study of tramadol/acetaminophen versus placebo in painful diabetic peripheral neuropathy. Curr Med Res Opi 2007; 23:147-161

121. Hollingshead J, Dühmke RM, Cornblath DR. Tramadol for neuropathic pain. Cochrane Database Syst Rev 2006 Jul 19; 3:CDoo3726.

122. Arbaiza D, Vidal O. Tramadol in the treatment of neuropathic cancer pain: $A$ double-blind, placebo-controlled study. Clin Drug Investig 2007; 27:75-83.

123. Norrbrink C, Lundeberg T. Tramadol in neuropathic pain after spinal cord injury: A randomized, double-blind, placebo-controlled trial. Clin J Pain 2009; 25:177-184

124. Vadovelu N, Timchenko A, Huang $Y$, Sinatra R. Tapentadol extended-release for treatment of chronic pain: A review. J Pain Res 2011; 4:211-218

125. Christoph T, De Vry J, Tzschentke TM. Tapentadol, but not morphine, selectively inhibits disease-related thermal hyperalgesia in a mouse model of diabetic neuropathic pain. Neurosci Lett 2010;470:91-94.

126. Schröder W, Vry JD, Tzschentke TM, Jahnel U, Christoph T. Differential contribution of opioid and noradrenergic mechanisms of tapentadol in rat models of nociceptive and neuropathic pain. Eur J Pain 2010; 14:814-821.

127. Bee LA, Bannister K, Rahman W, Dickenson $\mathrm{AH}$. Mu-opioid and noradrenergic $\alpha(2)$-adrenoceptor contributions to the effects of tapentadol on spinal electrophysiological measures of nociception in nerve-injured rats. Pain 2011; 152:131-139.

128. Schwartz S, Etropolski M, Shapiro
DY, Okamoto A, Lange R, Haeussler J, Rauschkolb C. Safety and efficacy of tapentadol ER in patients with painful diabetic peripheral neuropathy: Results of a randomized-withdrawal, placebocontrolled trial. Curr Med Res Opin 2011; 27:151-162.

129. Bruera E, Sweeney C. Methadone use in cancer patients with pain. J Palliative Med 2002; 5:127-137.

130. Kristensen K, Blemmer T, Angelo HR, Christrup LL, Drenck NE, Rasmussen SN, Sjøgren P. Stereoselective pharmacokinetics of methadone in chronic pain patients. Ther Drug Monit 1996; 18:221227.

131. Scott CC, Robbins EB, Chen KK. Pharmacologic comparison of the optical isomers of methadone. J Pharmacol Exp Ther 1948; 93:282-286.

132. Kristensen K, Christensen CB, Christup LL. The mu1, mu2, delta, kappa opioid receptor binding profiles of methadone stereoisomers and morphine. Life Sci 1995; 56:PL45-50

133. Bot G, Blake AD, Li S, Reisine T. Opioid regulation of the mouse opioid receptor expressed in human embryonic kidney 293 cells. Mol Pharmacol 1997; 53:272-281.

134. Codd EE, Shank RP, Schupsky JJ, Raffa RB. Serotonin and norepinephrine uptake inhibiting activity of centrally acting analgesics: Structural determinants and role in antinociception. J Pharmacol Exp Ther 1995; 274:1263-1270.

135. Lemberg K, Kontinen VK, Viljakka K, Kylänlahti I, Yli-Kauhaluoma J, Kalso E. Morphine, oxycodone, methadone and its enantiomers in different models of nociception in the rat. Anesth Analg 2006; 102:1768-1774.

136. Altier N, Dion D, Boulanger $A$, Choinière $M$. Management of chronic neuropathic pain with methadone: A review of 13 cases. Clin J Pain 2005; 21:364-369.

137. Cortés CC, Posada RS, Hernando FV. Methadone for pain syndromes with predominant neuropathic features in cancer patients. J of Cancer Pain \& Symptom Palliation 2005; 1:7-10.

138. Gagnon B, Almahrezi A, Schreier G. Methadone in the treatment of neuropathic pain. Pain Res Manag 2003; 8:149154 .

139. Moulin DE, Palma D, Watling C, Schulz $V$. Methadone in the management of intractable neuropathic noncancer pain. Can J Neurol Sci 2005; 32:340-343.

140. Moulin D. Use of methadone for neuropathic pain. Pain Res Manage 2003; 
8:131-132.

141. Davis AM, Inturrisi CE. D-Methadone blocks morphine tolerance and $\mathrm{N}$ methyl-D-aspartate-induced hyperalgesia. J Pharmacol Exp Ther 1999; 289:10481053.

142. Pelissier T, Laurido C, Kramer V, Hernández A, Paeile C. Antinociceptive interactions of ketamine with morphine or methadone in mononeuropathic rats. Eur J Pharmacol 2003; 477:23-28.

143. Sotgiu ML, Valente M, Storchi R, Caramenti G, Biella GE. Cooperative Nmethyl-D-aspartate (NMDA) receptor antagonism and mu-opioid receptor agonism mediate the methadone inhibition of the spinal neuron pain-related hyperactivity in a rat model of neuropathic pain. Pharamcol Res 2009; 60:284290.

144. Juver JP, Figueiredo NV, Barrucand L, Tostes Mde A. Methadone to treat nononcologic neuropathic pain. Case reports. Rev Bras Anestesiol 2005; 55:450459.

145. Mannino R, Coyne P, Swainey C, Hansen LA, Lyckholm L. Methadone for cancer-related neuropathic pain: A review of the literature. J Opioid Manag 2006; 2:269-276.

146. Picard N, Cresteil T, Djebli N, Marquet P. In vitro metabolism study of buprenorphine: Evidence for new metabolic pathways. Drug Metab Dispos 2005; 33:689695.

147. Kouya PF, Hao JX, Xu XJ. Buprenorphine alleviates neuropathic pain-like behaviors in rats after spinal cord and peripheral nerve injury. Eur J Pharmacol 2002; 450:49-53.

148. Pergolizzi J, Böger RH, Budd K, Dahan A, Erdine S, Hans G, Kress HG, Langford R, Likar R, Raffa RB, Sacerdote P. Opioids and the management of chronic severe pain in the elderly: Consensus statement of an International Expert Panel with focus on the six clinically most often used World Health Organization Step III opioids (buprenorphine, fentanyl, hydromorphone, methadone, morphine, oxycodone). Pain Pract 2008; 8:287-313.

149. Likar R, Sittl R. Transdermal buprenorphine for treating nociceptive and neuropathic pain: Four case studies. Anesth Analg 2005; 100:781-785.

150. Penza P, Campanella A, Martini A, Melli G, Lombardi R, Camozzi F, Devigili G, Lauria G. Short- and intermediate-term efficacy of buprenorphine TDS in chronic pain neuropathies. J Peripher Nerv Syst 2008; 13:282-288.

151. Hans G. Buprenorphine--a review of its role in neuropathic pain.J Opioid Manag 2007; 3:195-206.

152. Guetti C, Angeletti C, Marinangeli F, Ciccozzi A, Baldascino G, Paladini A, Varrassi G. Transdermal buprenorphine for central neuropathic pain: Clinical reports. Pain Pract 2011; 11:446-452.

153. Induru RR, Davis MP. Buprenorphine for neuropathic pain-targeting hyperalgesia. Am ] Hosp Palliat Care 2009; 26:470-473.

154. Lampert A, O'Reilly AO, Reeh P, Leffler A. Sodium channelopathies and pain Pflugers Arch 2010; 460:249-263.

155. Leffler A, Frank G, Kistner K, Niedermirtl F, Koppert W, Reeh PW, Nau C. Local Anesthetic-like Inhibition of Voltage-gated $\mathrm{Na}+\mathrm{Channels}$ by the Partial $\mu$-opioid Receptor Agonist Buprenorphine. Anesthesiology 2012;116:1335-1346.

156. Leffler A, Reckzeh J, Nau C. Block of sensory neuronal $\mathrm{Na}+$ channels by the secreolytic ambroxol is associated with an interaction with local anesthetic binding sites. Eur J Pharmacol 2010; 630:19-28.

157. Leffler A, Reiprich A, Mohapatra DP, Nau C. Use-dependent block by lidocaine but not amitriptyline is more pronounced in tetrodotoxin (TTX)-Resistant Nav1.8 than in TTX-sensitive $\mathrm{Na}+$ channels. J Pharmacol Exp Ther 2007; 320:354364.

158. Kistner K, Zimmermann K, Ehnert C, Reeh PW, Leffler A. The tetrodotoxinresistant $\mathrm{Na}+$ channel $\mathrm{Na}(\mathrm{v}) 1.8$ reduces the potency of local anesthetics in blocking C-fiber nociceptors. Pflugers
Arch 2010; 459:751-763.

159. Yanagidate F, Strichartz GR. Local anesthetics. Handb Exp Pharmacol 2007:95127.

160. Haeseler G, Foadi N, Ahrens J, Dengler $\mathrm{R}$, Hecker H, Leuwer M. Tramadol, fentanyl and sufentanil but not morphine block voltage-operated sodium channels. Pain 2006; 126:234-244.

161. Brodin P, Skoglund LA. Dose-response inhibition of rat compound nerve action potential by dextropropoxyphene and codeine compared to morphine and cocaine in vitro. Gen Pharmacol 1990; 21:551-553.

162. Mizuta K, Fujita T, Nakatsuka T, Kumamoto $E$. Inhibitory effects of opioids on compound action potentials in frog sciatic nerves and their chemical structures. Life Sci 2008; 83:198-207.

163. Ogawa T, Miyamae T, Murayama K, Okuyama K, Okayama T, Hagiwara M, Sakurada S, Morikawa T. Synthesis and structure-activity relationships of an orally available and long-acting analgesic peptide, ND-amidino-Try-D-ArgPhe-MeDAla-OH (ADAMB). J Med Chem 2002; 45:5081-5089.

164. Mizoguchi $\mathrm{H}$, Watanabe $\mathrm{C}$, Watanabe $\mathrm{H}$, Moriyama K, Sato B, Ohwada K, Yonezawa A, Sakurada T, Sakurada S. Involvement of endogenous opioid peptides in the antinociception induced by the novel dermorphin tetrapeptide analog amidino-TAPA. Eur J Pharmacol 2007; 560:150-159.

165. Przewlocka B, Mika J, Labuz D, Toth G, Przewlocki R. Spinal analgesic action of endomorphines in acute, inflammatory and neuropathic pain in rats. Eur J Pharamcol 1999; 367:189-196.

166. Hanlon KE, Herman DS, Agnes RS, Largent-Milnes TM, Kumarasinghe IR, Ma SW, Guo W, Lee YS, Ossipov MH, Hruby VJ, Lai J, Porreca F, Vanderah TW. Novel peptide ligands with dual acting pharmacophores designed for the pathophysiology of neuropathic pain. Brain Res 2011;1395:1-11. 